\title{
Customer brand engagement impact on brand satisfaction, loyalty, and trust in the online context. Egyptian Banking Sector
}

\author{
Heba Sadek \\ Heba El Mehelmi \\ Arab Academy for Science, Technology and Maritime Transport \\ Alexandria, Egypt
}

\section{Keywords}

Brand Engagement, Online Brand Experience, Satisfaction, Loyalty, Trust, Egypt.

\begin{abstract}
This study measures the impact of customer brand engagement (CBE) on brand satisfaction, loyalty, and trust through the online brand experience in the Egyptian banking sector based on the customers' perspective. Electronic questionnaires were developed to collect data. Data collected from 392 questionnaires was analyzed by means of Structural Equation Modelling (SEM). Findings indicated that CBE has a significant positive impact on brand satisfaction, trust, and loyalty respectively via the online brand experience. This study contributes to knowledge development by focusing on the importance of CBE and its consequences in the online service sector, which is still uncovered. Besides, this study offers guidelines to the service providers with valuable meanings for $C B E$ to enhance brand's satisfaction, trust and loyalty via developing a unique online brand experience particularly in the Egyptian banking sector, which is witnessing now a new era of digital transformation.
\end{abstract}

Corresponding author: Heba Sadek

Email addresses for the corresponding author: heba_sadek@yahoo.co.uk

First submission received: $9^{\text {th }}$ June 2020

Revised submission received: $17^{\text {th }}$ June 2020

Accepted: 25th June 2020

\section{Introduction}

In the current competitive business environment, brands have been vital in strengthening relationships with customers to achieve a great success of businesses (Hollebeek et al., 2016). It has become essential to the organizations to provide brand value and superior services in the hope of engaging their customers more (Potdar et al., 2018). The customer's role in the interaction with the brand is at the center of the engagement concept (Patterson et al., 2006). Engagement with the brand is vital for the long-lasting brand-customer relationship, particularly for service brands (Chang and Fan, 2017; Potdar et al., 2018; Algharabat et al., 2020).

CBE is an emotional state that includes a customer's passion and desire for the brand (Brodie et al., 2011). This concept depends on the significance of participating customers in cooperative and co-creative experiences (Bijmolt et al., 2010; Brodie et al., 2011). Thus, CBE can provide both unique and memorable brand experiences, which will help in developing brand trust, satisfying customers, and promoting brand loyalty (Brodie et al., 2013; Hollebeek et al., 2016; Hollebeek et al., 2018; Iglesias et al., 2019). Currently, the advancement of the internet and the shift toward digital transformation have contributed to the progress of CBE and brand experience (Wirtz et al., 2010; Algharabat et al., 2020). Keeping an effective engagement with the user via frequent online interactions remains a vital issue for developing a unique and creative brand experience (Iglesias et al., 2019).

Despite the importance of this topic, previous studies such as Mollen and Wilson (2010); Hollebeek et al. (2014); Dessart et al. (2015); Dwivedi (2015); Zhang et al. (2017) and Iglesias et al. (2019) mentioned the need to provide a clear understanding of $\mathrm{CBE}$ and its consequences in a specific sector. Thus, this paper focuses specifically on the banking sector in Egypt due to its great importance and its vital role in the economy. Egypt has the biggest banking sector in North Africa (Oxford, 2019). The banking sector in Egypt is one of the oldest and largest in the region. It is one of the key pillars of the Egyptian economy. Since, it plays a crucial role in the development process in Egypt (El Essawi and Abd El Aziz, 2012). 
Egyptian banks keep evolving and adapting new technologies because today, customers are more influential. Customers can switch from one bank to another if they were not satisfied with the service. In Egypt, 75\% of banks offer internet banking services. And investing in technology is the future for the banking sector (Brussels Research Groups, 2019). Consequently, the severe competition and technological advancement have led the Egyptian banks to change their focus from service-oriented services to customer-oriented ones, which highlighted the need to focus more on CBE in the online banking context.

Besides, the previous studies were conducted in the European context and did not take into consideration the $\mathrm{CBE}$, the online brand experience, and its consequences, namely brand satisfaction, loyalty, and trust in a single study. The purpose of this paper is to provide a better interpretation and to fill the gaps found in the previous studies by focusing on the role of CBE on building brand satisfaction, loyalty, and trust via the online brand experience in one research model in the Egyptian banking sector. This study is organized as follows: First, the literature review of CBE, online brand experience, and their consequences. Second, the research methodology. Third, the results and analyses. Fourth, the discussion of the results followed by theoretical and practical implications. sixth, the conclusion and finally limitations and future directions are presented.

\section{Literature review \\ Customer Brand Engagement}

Customer engagement is a recurring interaction that takes place between a customer and an organization; this interaction reinforces the emotional, physical and or psychological relation the customer has with the organization (Phang et al., 2013; Hollebeek et al., 2014). Based on the above, customer engagement has been linked to improving corporate performance (Jaakkola and Alexander, 2014), gaining better competitive positions (Kumar and Pansari, 2016; Gong, 2018), creating new markets (Storbacka et al., 2016) and, boosting satisfaction of the customer and increasing loyalty and trust in the brand (So et al., 2014). Customer engagement is also linked to brand performance indicators such as sales development, customer participation and customer feedback (Sawhney et al., 2005; Bowden, 2009; Kumar et al., 2010; Van Doorn et al., 2010) other factors can also be attributed to engagement among them are cost reductions, superior profitability, brand recommendations and improved co-creative experiences (Bijmolt et al., 2010).

It has been proven that a customer engagement with a brand is not just the process of interaction between the customers and brands rather it is a fundamental tool in developing deeper customer-brand relationships. (Van Doorn et al., 2010; Hollebeek, 2011; Pratomo and Magetsari, 2018). Co-creation is what happens when the customer shows impulsive, unrestricted and flexible behaviors that exclusively customize the customer brand experience (Lusch and Vargo, 2006; Sprott et al., 2009). To develop customer engagement with a brand, it is also crucial for the brand organization to make marketing efforts (Ong et al., 2018; Prentice et al., 2019). Particularly in the service sector, as service companies provide intangible products that are hard for customers to realize before purchase. Consequently, studies recommend engaging customers in actions other than exchange, boosting a wider and more positive brand experience (Solem and Perderson, 2016). Currently, due to the internet companies can easily establish an ongoing dialogue with customers and develop an online experience toward the brand (Sawhney et al., 2005).

Most of the earlier studies viewed the brand experience as a consequence of CBE (Vivek, 2009; Ramaswamy and Gouillart, 2010; Brodie et al., 2011; Hollebeek, 2011; Hollebeek et al., 2014). Therefore, the company needs to enhance CBE to create a unique online brand experience (Pratomo and Magetsari, 2018). In the online banking sector, Nysveen and Pedersen (2014) suggested that building unique and favorable brand experiences and co-creation involvement should help to engage customers with the brand. Thus, a bank can create a positive and constructive online banking experience by improving the CBE of the bank's brand (France et al., 2016). Thus, based on the above arguments, the researchers assume that $\mathrm{CBE}$ impacts online brand experience and thus propose the following hypothesis:

H1. CBE has a significant positive direct impact on customer's online brand experience. 


\section{Online Brand Experience}

Brand experience can be described as the view of the customers, at every contact they perform with the brand, it can be through advertising, during the first face to face interaction, or shown in the level of quality and personal care they receive (Alloza, 2008). Brand experience is shown in the customer's spontaneous feelings of the brand (Kabadayi and Alan, 2012). Studies suggest that from the customer's point of view brand experience is essential for a holistic evaluation of the brand (Nysveen et al., 2013, Khan and Rahman, 2015). When a brand can deliver unique and favorable brand experiences, it can distinguish itself apart from competitors and attain its objectives (Brakus et al., 2009).

The brand experience differs in its power and can be either positive or negative, with extensive influence on customer behavior (Brakus et al., 2009). Rapid action and timed reply to negative commentaries as well kind attitude to customer complaints generate sincere effect on the customer's mind. This helps companies achieve promising insights of their brand and enriches their customer understanding. The company can attempt to more impact customers by offering a superior experience, consequently generating customer confidence, which will lead to customer loyalty (Potdar et al., 2018).

Brand experience doesn't stop at products and services in the marketplace; it is also originated from the online searching of products or services (Brakus et al., 2009). The development of communication technologies has resulted in online brands that bring online brand experiences to customers (Ha and Perks, 2005; Morgan-Thomas and Veloutsou, 2013; Lee and Jeong, 2014). Providing an exceptional brand experience in an online context is critical due to the energetic flow of information describing this distinctive electronic environment (Morgan-Thomas and Veloutsou, 2013; Lee and Jeong, 2014; Bleier et al., 2019).

Morgan-Thomas and Veloutsou (2013) described the online brand experience as a customer's personal response to the interaction with the online brand. Online brand experience is a quicker way to grasp the quality of experience and improve the interaction with the brand customers (Helm, 2007). Thus, online brand experience has originated from the idea of customer experience (Arnold et al., 2005). Ha and Perks (2005) defined web site based brand experience as a customer's affirmative navigations (using webbased groups and taking part in events) and opinions (the assortment, and uniqueness of optical displays and value for money) with a precise website.

\section{Online Brand Experience Consequences}

Based on the literature, we can identify three main behavioral outcomes of brand experience: 1brand satisfaction, 2- brand loyalty, and 3- brand trust (Khan and Fatma, 2017). First of all, Grace and $\mathrm{O}^{\prime}$ Cass (2004) and Ha and Perks (2005) suggested that brand experience has an influence on brand satisfaction. Besides, Brakus et al. (2009) showed that brand experiences deliver value to customers, which boosts their satisfaction with the brand. Based on Suh and Youjae (2006), customer satisfaction toward the brand is defined as an evaluation to direct consumption experience, between previous anticipation and the real performance noticed after consumption. Accordingly, when customers obtain positive brand experiences, this increases their satisfaction with the brand (Khan and Rahman, 2015). Studies in various fields like banking sector (Nysveen et al., 2013; Nysveen and Pedersen, 2014), retail sector (Khan and Rahman, 2015), online marketing (Ha and Perks, 2005) and online brands (Morgan-Thomas and Veloutsou, 2013; Lee and Jeong, 2014) have focused on customer satisfaction as an important consequence of brand experience.

A lot of studies have clarified the influence of brand experiences on brand satisfaction as well (Brakus et al., 2009; Nysveen et al., 2013; Khan and Rahman, 2015). Satisfaction is the psychological assessment of the brand by the customer, causing a touching and an emotional bond with the brand (Potdar et al., 2018). Good brand experience creates an emotional customer bond toward the brand and lastly, it will lead to brand satisfaction (Gentile et al., 2007; Chinomona, 2013; Kusuma, 2014). Thus, satisfaction is a consequence of online brand experiences (Janda and Ybarra, 2005; Flavián et al., 2006). Customers are expected to be satisfied with the brand via the pervasive and supported online brand experiences (Brakus et al., 2009). Hence, based on aforementioned arguments, the present study proposes that:

H2. Online brand experience has a significant positive direct impact on brand satisfaction. 
Second, many studies have recognized brand loyalty as a main result of brand experience in the setting of retail sector (Khan and Rahman, 2015), service sector (Nysveen et al., 2013) and banking sector (Nysveen and Pedersen, 2014). Brand loyalty by definition is a profoundly held guarantee to rebuy or support a favorite product/service constantly, so generating recurring same-brand, nevertheless situational effects that can cause switching behavior (Oliver, 1999).

Therefore, when customers make repeated visits and attain one of a kind brand experiences, they tend to build brand loyalty (Brakus et al., 2009). It was said by Morrison and Crane (2007) that developing and attaining distinctive brand experiences are vital to building service brand loyalty. Moreover, in the context of banking sector, Sikdar et al. (2015) showed that if the experience is constructive it produces a need for repeated usage. So, brand loyalty is suggested to be another outcome of brand experience. Previous studies also find that valuable brand experience has a very significant impact on brand loyalty (Brakus et al., 2009; Ramaseshan and Stein, 2014).

Gentile et al. (2007) explained that customers who experience a good brand can promote the creation of a solid relationship between the brand and the customer, which will then increase brand loyalty. Establishing customer brand relationships through a valuable brand experience will lead to brand loyalty (Kusuma, 2014; Cleff et al., 2018). Customers are expected have a solid relationship with the brand through the pervasive and strengthened online brand experiences (Brakus et al., 2009). Consequently, the more a customer feels a suitable brand experience, the more possible the customer will repurchase the brand, which will lead to brand loyalty (Pratomo and Magetsari, 2018). Based on the above arguments, the following hypothesis is presented:

\section{H3: Online brand experience has a significant positive direct impact on brand loyalty.}

Third, customers' experience with a brand acts as an important resource for individual input that develops trust toward the brand (Ha and Perks, 2005). Brand trust is defined as a sentiment of safety detained by the customer based on his/her connection with the brand, it is derived from the perceptions that the brand is dependable for the benefits of the customer (Ha and Perks, 2005). Based on the above, customers build trust toward a brand based on their experience with this brand (Ramaseshan and Stein, 2014). When the customer experience something that is extremely related to him, he feels safe about the capability of the brand to meet guarantees, which in turn creates trust toward this brand (DelgadoBallester and Munuera-Aleman, 2001). Studies showed that brand trust is an outcome of brand experience (Ramaseshan and Stein, 2014). Consequently, brand trust is the outcome of customers' positive brand experiences (Ha and Perks, 2005; Brakus et al., 2009). Thus, this study suggests the following hypothesis.

H4: Online Brand experience has a significant positive direct impact on brand trust.

Based on the previous studies, the subsequent conceptual model has been shown in figure (1).

Figure (1): Conceptual Framework

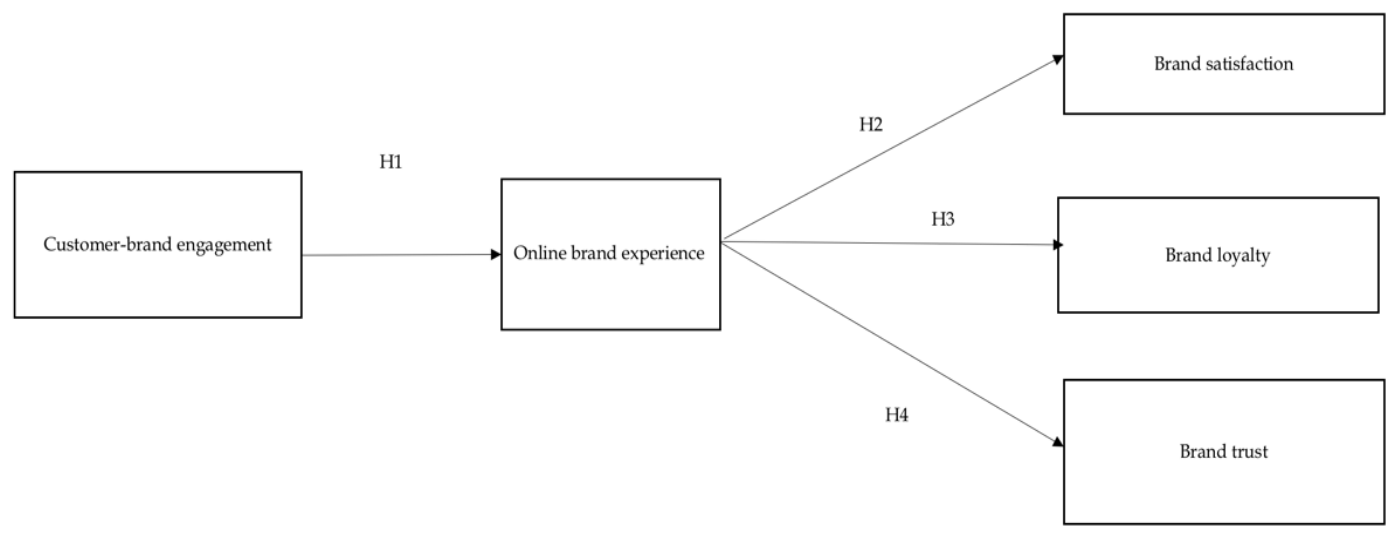




\section{Methodology}

A quantitative approach was developed to test the research hypotheses, the sampling technique used in this study was convenience sampling technique and the sample consisted of online banking customers. Those customers were selected according to the standards recommended by Parasuraman et al. (2005) that propose that customers must have a minimum of 1 online bank account, 4 months of online bank experience, and 2 transactions/month. The electronic questionnaire was chosen for many reasons, for example, the fast sharing of the questionnaire without time or geographic limitations, the familiarity today with new technologies, the lack of monetary cost to complete the research, the easy input of responses to an online spreadsheet, making it simple to store responses and monitor the flow of results while only fully answered questionnaires are accepted and avoiding possible missing values which confuse the statistical analysis of results. The researchers distributed the questionnaire electronically by using Google forums. This was achieved by sending messages with the survey link to respondents through WhatsApp and Facebook.

Respondents were asked to select one bank to answer the questionnaire based on his/her choice. The questionnaire consists of five sections in addition to the demographic section. Every section presents a research variable. The items of all research variables were adopted from prior studies and amended to the banking sector. Ten items from Hollebeek et al. (2014) to measure CBE. Five items from the study of Morgan-Thomas and Veloutsou's (2013) to measure online brand experience. Three items from Fornell (1992) and Oliver (1980) to measure brand satisfaction. Three items from the work of Nysveen and Pedersen (2014) to measure brand loyalty, thirteen items from Dimitriadis and Kyrezis (2008) to measure brand trust.

First, a pilot study has been conducted with a total number of 51 bank customers to check the convergent validity and reliability of the questionnaire. Based on the pilot study, it has been found that all methods used to assess the convergent validity showed good values, and all indicators have good factor loadings with reliability that exceeds the threshold of 0.6 , which is satisfactory for the reliability of scales (Hair et al., 2010). Moreover, the average variance extracted for the research constructs showed values over 0.5 which is considered adequate for confirming convergent validity based on Hair et al. (2010) as shown in the next part in table (1).

\section{Convergent Validity and Reliability}

Factor analysis (FA) was examined to evaluate the convergent validity of research variables. KaiserMeyer-Olkin (KMO) and Bartlett's Test were measured in this study. Based on Hair et al. (2010), KMO returns values are between 0 and 1 and the values closer to 1 are better. Moreover, a significant Bartlett's test of sphericity is needed while $\mathrm{p}$ is less than 0.001 (Bartlett, 1951). Confirmatory factor analysis (CFA) was used to evaluate the convergent validity of the items of the variables. For researchers using CFA, the loadings of 0.30 or more for sample sizes of 350 or superior will be appropriate (Hair et al., 2010). Additionally, the average variance extracted (AVE) for the research variables were examined for confirming the convergent validity that should be 0.5 or greater based on Hair et al. (2010). Cronbach's alpha was used to examine the reliability of the research variables. For researchers using Cronbach's alpha, Cronbach's alphas values should exceed 0.6 (Nunnally and Bernstein, 1994).

Table (1) summarizes the results of KMO, Bartlett's Test, minimum factor loadings, AVE, and Cronbach's alpha of the research variables

\begin{tabular}{|l|l|l|l|l|l|}
\hline Research Variables & KMO & Bartlett's Test & $\begin{array}{l}\text { (Minimum factor } \\
\text { loadings) }\end{array}$ & AVE & Cronbach's alpha \\
\hline $\begin{array}{l}\text { Customer brand } \\
\text { engagement (CBE) }\end{array}$ & 0.926 & $\begin{array}{l}702.751 \\
(0.000)\end{array}$ & 0.869 & $83.840 \%$ & 0.978 \\
\hline $\begin{array}{l}\text { Online brand } \\
\text { experience }\end{array}$ & 0.912 & $\begin{array}{l}268.5 \\
(0.000)\end{array}$ & 0.914 & $86.078 \%$ & 0.959 \\
\hline Brand satisfaction & 0.764 & 153.0 & 0.941 & $91.374 \%$ & 0.951 \\
\hline Brand loyalty & 0.739 & 158.9 & 0.944 & $91.572 \%$ & 0.953 \\
\hline Brand trust & 0.932 & 969.6 & 0.882 & $83.589 \%$ & 0.998 \\
\hline
\end{tabular}


From table (1), the findings showed that $\mathrm{KMO}$ values between 0.7 and 1 , which indicate that the sampling is adequate. All the values of Bartlett's are significant at 0.000 . Additionally, all indicators have good factor loadings ranging between 0.882 till 0.944 with reliability that exceeds the threshold of 0.6 (Hair et al., 2010) ranging from 0.951 to 0.998 , which indicates a good level of reliability (Nunnally and Bernstein, 1994). Moreover, AVE for the research constructs showed values over $50 \%$ ranging between $83.589 \%$ till $91.572 \%$ which is considered adequate for confirming convergent validity based Hair et al. (2010).

\section{Results and analysis}

The AMOS 22 was used to conduct the SEM. First of all, the descriptive statistics for the research sample have been conducted. Then, the goodness-of-fit of the measurement model should be checked. Therefore, the model fit indices were conducted before testing the research hypotheses as presented in table (2).

\section{Descriptive Statistics for the Research Sample}

The sample size of the research was 392 bank customers. From the public sector, there were 90 customers that constitute (22\%) of the total sample from different banks such as National Bank of Egypt, Bank Misr and, Banque du Caire. From the private sector, there were 302 customers that constitute (78\%) of the total sample from different banks such as Arab African International Bank, CIB, Credit Agricole, HSBC and QNB.

\section{Model Fit Indices}

In order to analyze the hypothesized relationships through the means of the SEM. The goodness-offit of the measurement model should be checked. Therefore, the following model fit indices were conducted before testing the research hypotheses as presented in table (2).

Table (2): Model fit Indices

\begin{tabular}{|l|l|l|l|l|l|}
\hline & CMIN/DF & RMR & CFI & NFI & RMSEA \\
\hline Measurement model & 3.7 & 0.033 & 0.948 & 0.931 & 0.083 \\
\hline SEM model & 3.1 & 0.029 & 0.961 & 0.943 & 0.073 \\
\hline $\begin{array}{l}\text { The best result } \\
\text { according to } \\
\text { Hair } \text { et al., (2010) }\end{array}$ & $\begin{array}{l}\text { Greater than 1 \& less } \\
\text { than 3(best result) } \\
3-5 \text { (acceptable level) }\end{array}$ & $\begin{array}{l}\text { Less } \\
\text { than } \\
10 \%\end{array}$ & Greater than 0.9 & $\begin{array}{l}\text { Greater than } \\
0.9\end{array}$ & $\begin{array}{l}\text { Less than 0.08 is } \\
\text { acceptable and Less } \\
\text { than 0.05 is good }\end{array}$ \\
\hline
\end{tabular}

From table (2), it has been shown that all model fit indices have been improved after adding the relationships to the model, for example the CMIN/DF, RMR, CFI, NFI and RMSEA of the measurement model were $3.7,0.033,0.948,0.931$ and 0.083 respectively. After adding the relationships, it has been found that the CMIN/DF, RMR, CFI, NFI and RMSEA have been improved to be 3.1, 0.029, 0.961, 0.943 and 0.073 correspondingly, which indicates an acceptable level of the good fit of the model based on Hair et al., (2010).

\section{Testing the Research Hypotheses}

The AMOS output for the model parameter estimates is reflected in table (3). Based on Hair et al. (2010), any number of a critical ratio (CR) over 1.96 or p-value less than 0.05 is significant in the model.

Table (3): The standardized estimate, CR and P Value

\begin{tabular}{|lll|lllllll|}
\hline $\begin{array}{l}\text { Hypotheses } \\
\text { Numbers }\end{array}$ & $\begin{array}{l}\text { Research } \\
\text { hypotheses }\end{array}$ & Estimate & S.E. & C.R. & P-Value & $\begin{array}{l}\text { Standardized } \\
\text { Regression } \\
\text { Weights }\end{array}$ & Results \\
\hline H1 & BE. & $<---$ & CBE. & .958 & .030 & 31.425 & $* * *$ & .970 & $\begin{array}{l}\text { Supported at 5\% } \\
\text { significance level }\end{array}$ \\
H2 & BS. & $<---$ & BE. & 1.021 & .029 & 35.390 & $* * *$ & .973 & $\begin{array}{l}\text { Supported at 5\% } \\
\text { significance level } \\
\text { H3 }\end{array}$ \\
BL. & $<---$ & BE. & 1.016 & .030 & 33.902 & $* * *$ & .956 & $\begin{array}{l}\text { Supported at 5\% } \\
\text { significance level } \\
\text { H4 }\end{array}$ \\
BT. & $<---$ & BE. & 1.012 & .031 & 33.168 & $* * *$ & .970 & $\begin{array}{l}\text { Supported at 5\% } \\
\text { significance level }\end{array}$ \\
\hline
\end{tabular}

Note: BE: online brand experience, CBE: customer-brand engagement, BT: brand trust, BL: brand loyalty, BS: brand satisfaction. 
The statistics show that all the path coefficient results seemed to be significant at $5 \%$ significance level, which means that all research hypotheses were supported with p-values less than 0.05 (as showed in table 3). For the first research hypothesis, it has been shown that CBE has a significant positive direct impact on online brand experience with a standardized estimate of 0.970 . This means that when the customer is well engaged with the bank, this will create a unique and favorable online brand experience. For the second research hypothesis, it has been shown that online brand experience has the greatest positive direct impact on brand satisfaction with a standardized estimate of 0.973 . This means that when the customer has a strong, unique and favorable online brand experience, this will boost the customer's happiness and pleasure toward the bank. For the third research hypothesis, it has been found that the online brand experience has a significant positive direct impact on brand loyalty with a standardized estimate of 0.956 . This means that when the customer has a strong, positive and unique online brand experience, this will help the customer to have strong bond with the bank, which will build strong customer's loyalty toward the bank. For the fourth research hypothesis, it has been found that the online brand experience has a significant positive direct impact on brand trust with a standardized estimate of 0.970 . This means that when a customer has a respectable and a satisfactory online brand experience, this will increase and develop the customer's trust toward the bank.

\section{Indirect Effect}

Direct effects have been examined previously in the above section in table (3). This part will focus on the indirect effects. As shown in table (4), there are indirect effects from CBE to brand trust, brand loyalty and brand satisfaction through online brand experience. Table (4) illustrates these indirect effects.

Table (4): Standardized indirect effects

\begin{tabular}{|lll|llll|}
\hline \multicolumn{2}{|l|}{\begin{tabular}{l} 
Standardized Indirect Effects Bias- \\
\multicolumn{2}{|c|}{ corrected percentile method }
\end{tabular}} & Estimate & $\begin{array}{c}\text { Lower } \\
\text { Bounds }\end{array}$ & $\begin{array}{c}\text { Upper } \\
\text { Bounds }\end{array}$ & $\begin{array}{c}\text { Two Tailed } \\
\text { Significance }\end{array}$ \\
\hline BT & $<---B E$ & $<---C B E$ & 0.941 & 0.917 & 0.958 & 0.003 \\
BL & $<---B E$ & $<---C B E$ & 0.927 & 0.899 & 0.946 & 0.003 \\
BS & $<---B E$ & $<---C B E$ & 0.943 & 0.921 & 0.96 & 0.003 \\
\hline
\end{tabular}

Note: BE: online brand experience, CBE: customer-brand engagement, BT: brand trust, BL: brand loyalty, BS: brand satisfaction

From table (4), the indirect effects are significant at 0.05 significance level. The CBE shows the strongest indirect effect on the brand satisfaction (standardized estimate $=0.943$ ) via the online brand experience, while the CBE shows the weakest indirect effect on the brand loyalty (standardized estimate = 0.927) via the online brand experience. Based on this table, it has been found that online brand experience acts as a mediator between CBE and brand satisfaction, loyalty and trust, which indicates the crucial role of online brand experience in leading to high customer's satisfaction, loyalty and trust toward the bank. And also, it highlights the importance of customer's participation and engagement in order to have a unique and favorable online brand experience.

Figure (2): Final Model

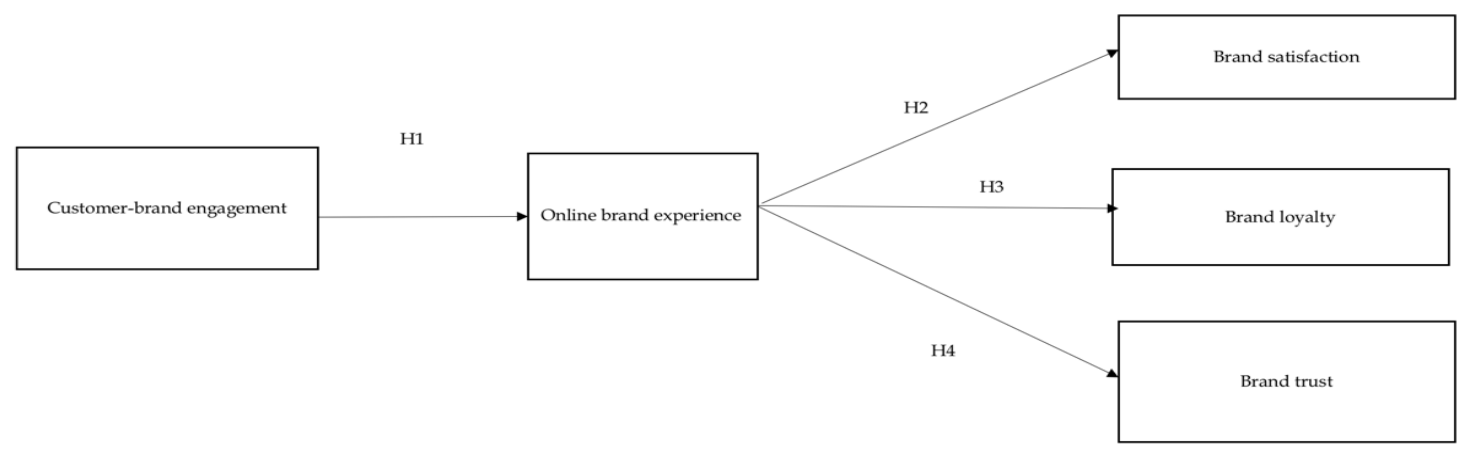

Independent Variable

Mediator Variable

Dependent Variables

Note: All research hypotheses were supported at 5\% significance level 


\section{Discussion}

The research findings showed that CBE has a significant positive direct impact on online brand experience. Besides, it has been shown that online brand experience has a significant positive direct impact on consumer behavioral outcomes: brand satisfaction, trust, and loyalty respectively. In other words, by increasing the level of CBE the bank can enhance the degree of satisfaction, build trust, and foster loyalty toward the bank more successfully via creating a unique online brand experience.

Concerning the significant positive direct impact of CBE on online brand experience in the Egyptian banking sector, this study finding matches with the previous studies of Khan et al. (2016) and Pratomo and Magetsari (2018) who mentioned that companies must capitalize on brand engagement in fostering a unique online brand experience. $\mathrm{CBE}$ in the banking industry helps customers to interact directly with banks through the use of online banking such as internet banking and mobile applications and hence improve customers' online brand experience. Additionally, this finding matches with Mollen and Wilson (2010) who focused on the great impact of CBE on online brand experiences in the online branding literature. Other studies such as Hollebeek et al. (2014), Nysveen and Pedersen (2014), and France et al. (2016) affirmed that brand experience is considered as a consequence of CBE. They mentioned that a bank can create a positive and constructive online banking experience by improving the CBE of the bank's brand.

Moreover, it has been showed that the online brand experience has a significant positive direct impact on brand satisfaction in the Egyptian banking sector. This finding was supported by the prior studies of Pratomo and Magetsari (2018) who mentioned that the higher the brand experience achieved by the customer, the higher the level of satisfaction in the banking industry. Besides, other studies such as Chinomona (2013), Kusuma (2014) and Khan et al. (2016) stated that the higher the brand experience of a brand, the higher the brand's satisfaction in the eyes of customers. In more detail, good brand experience creates an emotional customer bond toward the brand and lastly, it will lead to brand satisfaction. Consequently, customers having a superior online brand experience will lead to improved customer satisfaction with the brand.

Likewise, it has been demonstrated in this study that it exists a significant positive direct impact of online brand experience on brand loyalty in the Egyptian banking sector, which is in line with the previous studies of Klaus et al. (2013), Francisco-Maffezzolli et al. (2014), Ramaseshan and Stein (2014), Khan and Rahman (2015), and Pratomo and Magetsari (2018) who found that online brand experience has a significant positive direct impact on brand loyalty. This means that when the online brand experience is superior, loyalty towards the brand increases. The higher the customer experience, the more likely that they will repeat the same experience and generate loyalty toward the brand. Thus, the more a customer feels a good and suitable brand experience, the more possible the customer will repurchase, which will lead to brand loyalty. As well, this study finding matches the findings of the research conducted by Khan and Rahman (2016) and Khan et al. (2016) about banking customers in Delhi, India; which presented that brand experience has a positive influence on brand loyalty.

For the significant positive direct impact of online brand experience on brand trust, it was reinforced by the earlier studies of Pratomo and Magetsari (2018) who found that the higher the brand experience felt by the customer, the higher the level of trust towards the brand. Previous studies carried out by Ramaseshan and Stein (2014), and Lee and Jeong (2014) showed that brand trust is an outcome of brand experience. Additionally, Khan and Fatma (2017) mentioned that positive online brand experiences will increase customers' trust. Finally, the rationality of this study is that CBE can develop online brand experience, and subsequently, the developing online brand experience will influence brand satisfaction, brand loyalty, and brand trust.

\section{Implications}

This study builds on the body of knowledge by focusing on the crucial role of CBE in a new context, which is the Egyptian online banking sector. These findings provide valuable understandings into what contributes to the development of unique and favorable online brand experience to achieve high brand satisfaction, loyalty, and trust to be able to win the competition and to stand high in the cloud. This study provides theoretical and practical implications. For the theoretical implications, this study addresses several theoretical contributions. First, previous studies (such as Hollebeek et al., 2014; Wang et al., 2018) 
explained that the notion of CBE is still uncovered. Hence, we react to the call of the previous studies to develop more research in other sectors and dissimilar cultures to understand more the concept of CBE by focusing on one of the most crucial sectors that play a crucial role in North Africa, which is the Egyptian banking sector. Second, this study tests the main consequences of the online brand experience proposed in the present study by combining brand satisfaction, loyalty, and trust. Thus, this study gives more complete picture than the other previously developed by integrating the $\mathrm{CBE}$, online brand experience, and its main consequences in one research model.

For the practical implications, this study showed the crucial role of $\mathrm{CBE}$ and its power to allow brand managers particularly, bank managers to provide customers with a more favorable brand experience using online banking services, which will lead to high brand satisfaction, loyalty and trust. Thus, this study offers valuable insights to bank managers that should be taken into consideration. First, banks need to capitalize on online settings including their websites and social media which are the exceptional tools that assist in increasing engagement among their customers. Second, the online brand experience can be enriched through developing user-friendly applications, websites, and other social media platforms. Third, more attention should be devoted to the service providers through developing advanced training programs to improve their skills and capabilities to delight their customers. Fourth, managers should consider planning a marketing strategy to participate the customers with the brand, which will motivate customers' brand experiences in an online setting. Bank managers should successfully design their online banking medium and integrate it into their marketing strategies. This is will be done through sharing feedback, reviews, and comments to maintain cooperative and collaborative conversations with customers. Particularly, in the online experience, companies need to act fast and share information to build better relationships with customers, keep their promises, and develop loyalty programs to achieve customer satisfaction, trust, and loyalty.

\section{Conclusion}

The dynamic competition in the banking industry and the significant role of branding supports the concept of online brand experience specifically for the service providers. Therefore, the crucial idea of this study was to examine the impact of CBE on customer behavioral outcomes, namely brand satisfaction, brand loyalty, and brand trust through online brand experience within the banking sector in Egypt. To conclude, it has been shown that CBE has a significant positive impact on brand satisfaction, trust, and loyalty respectively via the online brand experience, which highlights the importance of the mediation effect of online brand experience between CBE and consumers' behavioral outcome that offers valuable insights to financial institutions particularly bankers. Hence, banks need to capitalize on online settings including their websites and social media which are the exceptional tools that assist in increasing engagement among their customers to be able to satisfy their customers, build their trust, and gain their loyalty in today's competitive business environment.

\section{Limitations and future research}

This study was conducted in the Egyptian banking sector. Future research can test the proposed model in other sectors (such as the online hotel booking, retailing, and telecommunication sector) and other countries as well. This study only examined the CBE as an antecedent of online brand experience as well as its consequences. Further research should consider other antecedents of online brand experience such as brand perceived quality as well as the antecedents of CBE such as brand involvement. This study focused on $\mathrm{CBE}$ as a single construct. Future research may examine $\mathrm{CBE}$ as a multi-dimensional construct, taking into consideration several dimensions as cognitive processing, affection, and activation, as well as considering the level of customer engagement to better explain why some banks and other sectors are successful in engaging customers than others. This study used a convenience sampling technique due to the difficulty of obtaining a sampling frame of bank customers. However, the researchers attempted to decrease bias by distributing an electronic questionnaire to reach more respondents. Future research needs to use a probability sampling technique to be able to generalize the research findings. 


\section{References}

Algharabat, R., Rana, N., Alalwan, A., Baabdullah, A. \& Gupta, A.(2020), Investigating the antecedents of customer brand engagement and consumer- based brand equity in social media, Journal of Retailing and Consumer Services, Vol.53 No.1, pp.101767.

Alloza, A. (2008), Brand engagement and brand experience at BBVA, the transformation of a 150-year-old company, Corporate Reputation Review, Vol.11 No.4, pp. 371-379.

Anderson, J.C. \& Gerbing, D.W. (1988), Structural equation modeling in practice: A review and recommended twostep approach, Psychological Bulletin, Vol.103 No.3, pp.411.

Arnold, M.J., Reynolds, K.E., Ponder, N. \& Lueg, J.E. (2005), Customer delight in a retail context: investigating delightful and terrible shopping experiences, Journal of Business Research, Vol.58 No.8, pp. 1132-1145.

Bartlett, M. S. (1951), The effect of standardization on a Chi-square approximation in factor analysis, Biometrika, Vol.38 No.3/4, pp.337-344.

Bijmolt, T.H., Leeflang, P.S., Block, F., Eisenbeiss, M., Hardie, B.G., Lemmens, A. \& Saffert, P. (2010), Analytics for customer engagement. Journal of Service Research, Vol.13 No.3, pp.341-356.

Bleier, A., Harmeling, C.M. \& Palmatier, R.W. (2019), Creating Effective Online Customer Experiences, Journal of Marketing, Vol.83 No.2, pp. 98-119.

Bowden, J.L.H. (2009), The process of customer engagement: A conceptual framework, Journal of Marketing Theory and Practice, Vol.17 No.1, pp. 63-74.

Brakus, J.J., Schmitt, B.H. \& Zarantonello, L. (2009), Brand experience: what is it? How is it measured? Does it affect loyalty? Journal of Marketing, Vol.73 No.3, pp. 52-68.

Brodie, R.J., Hollebeek, L.D., Jurić, B. \& Ilić, A. (2011). Customer engagement: conceptual domain, fundamental propositions, and implications for research, Journal of Service Research, Vol.14 No.3, pp. 252-271.

Brodie, R.J., Ilic, A., Juric, B. \& Hollebeek, L. (2013), Consumer engagement in a virtual brand community: An exploratory analysis, Journal of Business Research, Vol. 66 No.1, pp.105-114.

Brussels Research Groups (2019). Egypt's Banking Sector Remains Resilient. Retrieved on May, 202020 from https://brusselsresearchgroup.org/index.php/2019/02/03/egypts-banking-sector-remains-resilient/

Chang, S.-W. \& Fan, S.-H. (2017), Cultivating the brand-customer relationship in Facebook fan pages: a study of fastfashion industry, International Journal of Retail E Distribution Management, Vol.45 No.3, pp. 253-270.

Chinomona, R. (2013), The influence of brand experience on brand satisfaction, trust and attachment in South Africa, International Business E Economics Research Journal (IBER), Vol.12 No.10, pp. 1303-1316.

Cleff, T., Walter, N. \& Xie, J. (2018), The Effect of Online Brand Experience on Brand Loyalty: A Web of Emotions, IUP Journal of Brand Management, Vol.15 No.1, pp. 8-24.

Delgado-Ballester, E. \& Luis Munuera-Alemán, J. (2001), Brand trust in the context of consumer loyalty, European Journal of Marketing, Vol.35 No.11/12, pp. 1238-1258.

Dessart, L., Veloutsou, C. \& Morgan-Thomas, A. (2015), Consumer engagement in online brand communities: a social media perspective, Journal of Product \& Brand Management, Vol.24 No.1, pp. 28-42.

Dimitriadis, S. \& Kyrezis, N. (2008), Does trust in the bank build trust in its technology-based channels? Journal of Financial Services Marketing, Vol.13 No.1, pp.28-38.

Dwivedi, A. (2015), A higher-order model of consumer brand engagement and its impact on loyalty intentions, Journal of Retailing and Consumer Services, Vol. 24 No.1, pp.100-109.

El Essawi, N. \& Abd El Aziz, R. (2012), Determining the main dimensions that affect e-customer relationship management readiness in the Egyptian banking industry, International Journal of Electronic Customer Relationship Management, Vol.6 No.3/4, pp. 217-234.

Flavián, C., Guinalíu, M. \& Gurrea, R. (2006), The role played by perceived usability, satisfaction and consumer trust on website loyalty, Information \& Management, Vol.43 No.1, pp.1-14.

Fornell, C. (1992), A national customer satisfaction barometer: The Swedish experience, Journal of Marketing, Vol.56 No.1, pp. 6-21.

France, C., Merrilees, B. \& Miller, D. (2016), An Integrated Model of Customer-Brand Engagement: Drivers and Consequences, Journal of Brand Management, Vol.23 No.2, pp.119-136.

Francisco-Maffezzolli, E.C., Semprebon, E. \& Prado, P.H.M. (2014), Construing loyalty through brand experience: the mediating role of brand relationship quality. Journal of Brand Management, Vol.21 No.5, pp.446-458.

Gentile, C., Spiller, N. \& Noci, G. (2007), How to sustain the customer experience: An overview of experience components that co-create value with the customer, European Management Journal, Vol.25 No.5, pp.395-410.

Gong, T. (2018), Customer brand engagement behavior in online brand communities, Journal of Services Marketing, Vol.32 No.3, pp. 286-299.

Grace, D. \& O'Cass, A. (2004), Examining service experiences and post-consumption evaluations, Journal of Services Marketing, Vol.18 No.6, pp.450-461. 
Ha, H.-Y. \& Perks, H. (2005), Effects of consumer perceptions of brand experience on the web: Brand familiarity, satisfaction and brand trust, Journal of Consumer Behaviour: An International Research Review, Vol.4 No.6, pp.438452.

Hair, JF, Black, WC, Babin, BJ. \& Anderson, RE. (2010), Multivariate data analysis, 7th edn, Prentice Hall, New Jersey.

Helm, S. (2007), One reputation or many? Comparing stakeholders' perceptions of corporate reputation, Corporate Communications: An International Journal, Vol.12 No.3, pp.238-254.

Hollebeek, L.D. (2011). Demystifying customer brand engagement: Exploring the loyalty nexus. Journal of Marketing Management, 27 (7-8), pp. 785-807.

Hollebeek, L.D., Conduit, J. \& Brodie, R.J. (2016), Strategic Drivers, Anticipated and Unanticipated Outcomes of Customer Engagement, Taylor \& Francis.

Hollebeek, L.D., Glynn, M.S. \& Brodie, R.J. (2014), Consumer brand engagement in social media: Conceptualization, scale development and validation, Journal of Interactive Marketing, Vol.28 No.2, pp. 149-165.

Hollebeek, L.D., Jaakkola, E. \& Alexander, M. (2018), Beyond the dyadic: customer engagement in increasingly networked environments, Journal of Service Management, Vol.29 No.3, pp. 330-332.

Iglesias, O., Markovic, S. \& Rialp, J. (2019), How does sensory brand experience influence brand equity? Considering the roles of customer satisfaction, customer affective commitment, and employee empathy, Journal of Business Research, Vol.96 No.1, pp.343-354.

Jaakkola, E. \& Alexander, M. (2014), The role of customer engagement behavior in value co-creation: a service system perspective, Journal of Service Research, Vol.17 No.3, pp. 247-261.

Janda, S. \& Ybarra, A. (2005), Do product and consumer characteristics affect the relationship between online experience and customer satisfaction, Journal of Internet Commerce, Vol.4 No.4, pp.133-151.

Kabadayi, E.T. \& Alan, A.K. (2012), Brand trust and brand affect: Their strategic importance on brand loyalty. Journal of Global Strategic Management, Vol.11 No.6, pp.81-88.

Khan, I. \& Fatma, M. (2017), Antecedents and outcomes of brand experience: an empirical study, Journal of Brand Management, Vol.24 No.5, pp.439-452.

Khan, I. \& Rahman, Z. (2015), A review and future directions of brand experience research. International Strategic Management Review, Vol.3 No.1/2, pp. 1-14.

Khan, I. \& Rahman, Z. (2016), E-tail brand experience's influence on e-brand trust and e-brand loyalty: the moderating role of gender, International Journal of Retail E Distribution Management, Vol.44 No.6, pp.588-606.

Khan, I., Rahman, Z. \& Fatma, M. (2016), The role of customer brand engagement and brand experience in online banking, International Journal of Bank Marketing, Vol.34 No.7, pp.1025-1041.

Klaus, P., Gorgoglione, M., Buonamassa, D., Panniello, U. \& Nguyen, B. (2013), Are you providing the 'right' customer experience? The case of Banca Popolare di Bari, International Journal of Bank Marketing, Vol.31No.7, pp.506-528.

Kumar, R., Novak, J. \& Tomkins, A. (2010), Structure and evolution of online social networks. Link Mining: Models, Algorithms, and Applications, Springer, pp.337-357.

Kumar, V. \& Pansari, A. (2016), Competitive advantage through engagement, Journal of Marketing Research, Vol.53 No.4, pp.497-514.

Kusuma, Y.S. (2014), Pengaruh brand experience terhadap brand loyalty melalui brand satisfaction dan brand trust Harley Davidson di Surabaya, Jurnal Strategi Pemasaran, Vol.2 No.1, pp.1-11.

Lee, S.A. \& Jeong, M. (2014), Enhancing online brand experiences: An application of congruity theory. International Journal of Hospitality Management, Vol.40 No. (July), pp.49-58.

Lusch, R.F. \& Vargo, S.L. (2006), Service-dominant logic: reactions, reflections, and refinements. Marketing Theory, Vol.6 No.3, pp.281-288.

Mollen, A. \& Wilson, H. (2010), Engagement, telepresence, and interactivity in online consumer experience: Reconciling scholastic and managerial perspectives. Journal of Business Research, Vol.63 No.9/10, pp.919-925.

Morgan-Thomas, A. \& Veloutsou, C. (2013), Beyond technology acceptance: Brand relationships and online brand experience, Journal of Business Research, Vol.66 No.1, pp.21-27.

Morrison, S. \& Crane, F.G. (2007), Building the service brand by creating and managing an emotional brand experience, Journal of Brand Management, Vol.14 No.5, pp.410-421.

Nunnally, J.C. \& Bernstein, I.H. (1994), Psychometric Theory. (3 ed.), New York: McGraw-Hill.

Nysveen, H. \& Pedersen, P.E. (2014), Influences of co-creation on brand experience, International Journal of Market Research, Vol.56 No.6, pp.807-832.

Nysveen, H., Pedersen, P.E. \& Skard, S. (2013), Brand experiences in service organizations: Exploring the individual effects of brand experience dimensions, Journal of Brand Management, Vol.20 No.5, pp. 404-423.

Oliver R.L. (1999), Whence consumer loyalty? Journal of Marketing, Vol.63 No. (1), pp. 33-44.

Oliver, R.L. (1980), A cognitive model of the antecedents and consequences of satisfaction decisions, Journal of Marketing Research, Vol.17 No.4, pp.460-469. 
Ong, C.H., Lee, H.W. \& Ramayah, T. (2018), Impact of brand experience on loyalty, Journal of Hospitality Marketing $\mathcal{E}$ Management, Vol.27 No.7, pp.755-774.

Oxford (2019). The Report: Egypt 2019. Retrieved on April, 52020 from https://oxfordbusinessgroup.com/egypt2019/banking

Parasuraman, A., Zeithaml, V. \& Malhotra, A. (2005), E-S-QUAL: a multiple-item scale for assessing electronic service quality, Journal of Service Research, Vol.7 No.3, pp.213-234.

Patterson, P., Yu, T. \& De Ruyter, K. (2006), Understanding customer engagement in services, Advancing Theory, Maintaining Relevance, Proceedings of ANZMAC 2006 Conference, Brisbane, 4-6.

Phang, C.W., Zhang, C. \& Sutanto, J. (2013), The influence of user interaction and participation in social media on the consumption intention of niche products. Information $\mathcal{E}$ Management, Vol.50 No.8, pp.661-672.

Potdar, V., Joshi, S., Harish, R., Baskerville, R. \& Wongthongtham, P. (2018), A process model for identifying online customer engagement patterns on Facebook brand pages. Information Technology E People, Vol.31 No.2, pp.595614.

Pratomo, L.A. \& Magetsari, O.N.N. (2018), Online Brand Experience: Drivers and Consequences, Jurnal Dinamika Manajemen, Vol.9 No.2, pp. 218-227.

Prentice, C., Wang, X. \& Loureiro, S.M.C. (2019), The influence of brand experience and service quality on customer engagement. Journal of Retailing and Consumer Services, Vol.50 No.1, pp.50-59.

Ramaseshan, B. \& Stein, A. (2014), Connecting the dots between brand experience and brand loyalty: The mediating role of brand personality and brand relationships, Journal of Brand Management, Vol.21 No.7/8, pp. 664-683.

Ramaswamy, V. \& Gouillart, F.J. (2010), The Power of Co-Creation: Build It with Them to Boost Growth, Productivity, and Profits, Simon, and Schuster.

Sawhney, M., Verona, G. \& Prandelli, E. (2005), Collaborating to create: The Internet as a platform for customer engagement in product innovation, Journal of Interactive Marketing, Vol.19 No.4, pp. 4-17.

Sikdar, P., Kumar, A. \& Makkad, M. (2015), Online banking adoption: A factor validation and satisfaction causation study in the context of Indian banking customers, International Journal of Bank Marketing, Vol.33 No.6, pp.760785.

So, K.K.F., King, C. \& Sparks, B. (2014), Customer engagement with tourism brands: Scale development and validation, Journal of Hospitality E Tourism Research, Vol.38 No.3, pp.304-329.

Solem, B.A.A. \& Pedersen, P.E. (2016), The role of customer brand engagement in social media: conceptualisation, measurement, antecedents, and outcomes. International Journal of Internet Marketing and Advertising, Vol.10 No.4, pp.223-254.

Sprott, D., Czellar, S. \& Spangenberg, E. (2009), The importance of a general measure of brand engagement on market behavior: Development and validation of a scale, Journal of Marketing Research, Vol.46 No.1, pp.92-104.

Storbacka, K., Brodie, R.J., Böhmann, T., Maglio, P.P. \& Nenonen, S. (2016), Actor engagement as a microfoundation for value co-creation, Journal of Business Research, Vol.69 No.8, pp.3008-3017.

Suh, JC. \& Youjae, Y. (2006), When brand attitudes affect the customer satisfaction-loyalty relation: The moderating role of product involvement, Journal of Consumer Psychology, Vol.16 No.2, pp. 145-155.

Van Doorn, J., Lemon, K.N., Mittal, V., Nass, S., Pick, D., Pirner, P. \& Verhoef, P.C. (2010), Customer engagement behavior: theoretical foundations and research directions, Journal of Service Research, Vol.13 No.3, pp.253-266.

Vivek, S.D. (2009), A Scale of Consumer Engagement. PhD Thesis, University of Alabama Libraries.

Wang, S.S., Lin, Y.C. \& Liang, T.P. (2018), Posts that attract millions of fans: the effect of brand-post congruence. Electronic Commerce Research Applications. Vol.28 No. (March-April), pp.73-85.

Wirtz, B.W., Schilke, O. \& Ullrich, S. (2010), Strategic development of business models: implications of the Web 2.0 for creating value on the internet, Long Range Planning, Vol.43 No.2/3, pp.272-290.

Zhang, M., Hu, M., Guo, L. \& Liu, W. (2017), Understanding relationships among customer experience, engagement, and word-of-mouth intention on online brand communities: The perspective of service ecosystem, Internet Research, Vol.27 No.4, pp.839-857. 